\title{
Towards Inculcating Morality among the Youths in Nigeria: The Holy Family Youth Village Example
}

\author{
Amara M. Uzoigwe \\ DOI: http://dx.doi.org/10.4314/ujah.v14i1.10
}

\section{Abstract}

The youths form the essential segment of every human society. They are the driving force that determines the future and hope of the society. Any human society devoid of the youths is bound to collapse. The impact of the youths at home, church, community and the society at large cannot be overemphasized for they are most cherished by the human society. The youths like the yam stem, require the utmost attention of the society .In an attempt to realize themselves, youths are affected and influenced by the social environment and the social structure in which they live. It is, therefore, pertinent to acquaint youths with the basic veritable norms, values, social consciousness and code of conduct without which human co-existence would be impossible. The family, church, educational institutions and the State have a stake in this regard. This paper therefore, examines the effort of 'Holy Family Youth Village' towards inculcating morality among the contemporary youths in Nigeria. The paper concludes that the family, church and the state as agents of moral formation have irrevocable responsibility over the youths. However, individuals, industrialists and Non-Governmental Organizations (NGOs) could also venture into the welfare of the youths in Nigeria by initiating programmes that will ensure the realization of morally sound youths so as to ensure healthy human society. 


\section{Introduction}

The youths are the pivotal organ and fulcrum of every human society. They are filled with vigour, enthusiasm and vitality; they are ever ready to perform any kind of work at their disposal. As the work force of the state, youths are cherished by the human society and the society depends on the youths for result-oriented projects. Given their virility and ingenuity, youths remain the life wire of the society. Shakespeare in his poem the "Passionate Pilgrim" as cited by Maurus (2007) identifies youths as idol. Expressing his sentiments about the vitality of the youth, He says: "youth I adore thee." Considering the viability of the youth and their power of productivity, Maurus asserts that:

No one can spread light better than our young men and women. They have faith, confidence and energy...youth is fitter to invent a better society, fitter for new project which are linked to who and to what we are called to be, (p.17).

The youths have unquenchable force in the socioeconomic, political and religious structures of the human society. It could also be noted that in spite of the overwhelming population of the youth, their work force and vitality, youths still lean on the shoulders of the adult in search of meaning in life, self-realization and survival. Analyzing the position of the youth with regard to identity Obiefuna (2004) remarks:

Youths are more mature and active than infants and more energetic and creative than the older generation. At the same time, the youth are still at the level of searching for self discovery, growth, development and meaning in life, (p.59). 
Their dependence on the adult and the larger society for the realization of self however, laid bare the need for both the adult and the society to live by example and up to the standard norms and values of the society. This explains further the need for organized society for it is in an organized society that proper socialization could be realized. The level of organization of the society therefore, determines the stuff in terms of quality and productivity of the youth. Productivity in this context goes beyond the economic yield to every other facet of life. Based on the above point, it becomes imperative for the youth to be morally grounded, structured and nurtured for a better society.

It has been observed that the Nigerian society in spite of her rich natural and human resources is characterized by different kinds of social vices and ills. These vices are felt at different spheres of the society. They include corruption, bribery, embezzlement, misappropriation of public fund, injustice and so on with their end product as moral degeneration. The youths are the most devastatingly affected by these cankerworms that bedeviled our society. The above observed situation is indicative of the fact that Nigeria as a nation is eroded of morality. These ugly trends inhibit healthy human society. Some social analysts have attributed the problem with Nigeria as problem of leadership. Such assertion may not be disputed, but suffice it to say that the fundamental problem with the Nigerian society is lack of moral consciousness. The youth as the engine house and the future of the Nigerian society need to be acquainted with the basic moral values without which the nation would collapse and crash.

It is against this background that this paper examines the Holy Family Youth Village efforts towards inculcating morality among the youth in Nigeria .The paper would among 
other things explain the key concepts and establish the influence of the social environment on moral formation of the youths. The paper strongly upholds that moral formation of the youth is a collective effort of the members of the Nigerian society and if achieved would go a long way in rewriting the history of the Nigerian society.

\section{Clarification of Concepts Youth, Morality}

Attempt at defining youth as a concept has been a herculean task. This is because its approach by different scholars from various disciplines is subject to bias and prejudices. Different scholars define the concept of youth to suit specific purposes. Hence, there remains no consensus on the definition of the term youth .To some people, age bracket could account for who the youths are. Within such frame work, youths are those people who fall within the age limit of 18 or 21 and 30 or 40 while for some other people youth age is between the ages of 18-45. Whatever the case is, the fact remains that age bracket and physical vitality are always in a tussle in determining who the youths are. Some also define youth in the light of biological changes and make up as well as physiological virility and psychological deposits. According to Maurus (2007) psychologically youth is not a matter of years .Some are old at 20 and others are young at 80 . In other words, responsiveness of any human person to active life irrespective of age merits such a person a youth. However, Muorah representing Nwazojie's view as recorded in Obiefuna (2004) says:

Youth is not a period of life accurately determined by age, nor is it a period of life determined by biological and physiological changes in the body. It is a period of life which is basically determined by sociological factors, (p.12). 
The above point out rightly dispute for the place of age and biological changes in the body as determinants of who the youth is. Obviously, every field has its prejudice in defining the youth. Obiefuna (2004) citing Muorah who adopted Nwazojie's opinion, considers the position of the cultural anthropologists and psychologists while defining youths thus:

For cultural anthropologists youth is the time during which the human patrimony is handed on. This means that the youth is a period of principal socialization, a process by which the principal norms and values are inculcated in humans, (p.12).

At this stage of principal socialization, the human person is acquainted with the fundamental standard norms and values of the human society that guarantees harmonious co-existence. These values within this period are assimilated and internalized. On the part of the Psychologists, youth is described in terms of mental maturation and character development. For them maturation continues until one becomes fully autonomous. This view point could also be deficient in describing the youth because of some factors.

The bottom line is that there is no clear cut in defining the term youth. The point of emphasis is that in describing the youth there are salient factors that must be put in place. Youth should be considered in terms of psychological, cultural and sociological factors for they cut across each other in describing who the youth are. Obviously, youth age is a period of maturation. The cultural background provides formidable environment for socialization, while the psychological factors boost the character formation and development of the youth all geared towards self-realization. In this paper, youth should be 
understood as those human persons young, full of energy who have left the period of infancy, but are not yet adult who in the process of becoming, learn the norms and values and rules of the human society, internalizes them with the aim of realizing their potentials in life so as to achieve desired fulfillment in life.

\section{Morality}

Man fundamentally is a social being. The social nature of the human person spurs him to life of association and relationships for it is in the web of interrelationship that he (man) realizes himself. In the cause of relating with others, man gets socialized and demonstrates his gift of rationality which distinguishes him from every other animal. The result of his interaction in the web of interrelationship could either be good or bad. The faculty in man that guarantees the evaluation of man's actions in terms of right or wrong, good or bad is what we refer to as morality. And this brings to fore, the essential dimension of man as a moral being. As a moral being with gift of rationality, he takes the onus for his actions and inactions by way of praise or blame .In the light of the moral perspective, human actions thrive in an already established modality fashioned by the very nature of human existence. And this however, follows the stipulations of natural law. Shishim and Apenda as cited by Utusa (2010) traced the concept of morality to its ontological pedigree thus:

Morality is said to come from the Latin 'moralis' which means habits, customs, way of life and standards of human behaviour. The word is akin to the Greek 'ethos' which means character. This refers to good or bad, right or wrong behaviour, conduct etc, (p.53).

Eboh (2001) defines morality as the quality of being moral and to be moral is to conform to accepted good standard 
of behaviour. Apparently, there are set of moral principles that guide the activities of the human person in the human society and these standard principles are anchored on the provisions of natural law. As such, the natural law obliges all human beings to do good and avoid evil. It helps to protect and foster values. According to Omoregbe (2003) "moral principles are guides of the human conduct indicating certain kinds of actions, certain kinds of behaviour which should be avoided and certain other kinds of actions and behaviours which should be adopted" (p.68). Without these sets of moral norms and values, the patterned order of the social system of the human society would be truncated. In other words, there is a need for the human being to be abreast with those norms that guarantee harmonious societal life. Okwueze (2004) explains morality in terms of a specific form of social consciousness of awareness of your relatedness to others without which societal life would be impossible. Because, man is a social being that realizes himself in social relationships, he has a moral obligation therefore, to nurture that which is good that enhances harmonious co-existence and as well avoid that which breaks web of social relationships. Ugwu (2010) describes morality as "the astuteness of one's conduct and behaviour which enhances good conduct and fair relationship" (p.46).

Morality is neither found in isolation nor in the air but it is predicated upon the provisions of natural law. On this note, Monye (2010) remarked that morality does not suddenly appear out of nowhere. It is already embedded in the way of life an individual is born into, its attitudes, values and practices (p.244). Eboh added that "morality is founded on eco-justice and the dignity of the human person" (p.138). The above statements point to the level of societal organization, the home, and the social environment for these factors have inextricable influence on the moral formation of the human person. 
However, the concept of morality has become a complicated issue in the midst of multi-cultural world of today. This without mincing words could be attributed to westernization and modernization. Some people define morality either subjectively or objectively perhaps on the basis of what they consider ethically right or wrong. Inspite of the varied approaches to the concept of morality by different scholars, the bottom line is that morality is an indispensable concept in human society. Little wonder Iwenofu says:

It nurtures in a person those virtues and values that make him a good person, thus developing his thinking skills of moral judgment about what is right and wrong. It influences an individual on how he thinks feels and acts regarding issues of right and wrong, (p.51).

Where the human person upholds morality at a high esteem between the vertical and the horizontal web of inter relationship, the individual not only soars on a high pedigree, but the society also enjoys genuine growth and development.

\section{The Nigerian Youth and the Challenges of Immorality}

The assertion by Obiefuna (2010) that in a sense, human beings are product of their environment cannot be argued. Peil in Obiefuna understands human beings as product of their environment in terms of the interaction that exists between the individual and the society. Apparently, both the individual and the society engage in symbiotic kind of relationship in which the human person contributes to the societal wellbeing and the society in turn builds the human persons that form a part of that society. This brings to limelight, the indispensability of an esteemed level of organization of the society by way of her social system and structure. Hence, if the socio-political structure and system of the society is standard, it would reflect in the overall life and activities of the people. In fact, the level 
of organization of any human society has a lot of influence on the people that make up that society.

Records have shown that Nigeria, in spite of her astute human and natural resources, is morally bankrupt. There is an increase in willful moral dethronement and immoral enthronement in our society. The youths as part and parcel of the Nigerian society are not left out in this morass that bedevils Nigeria. The effects of moral decadence in the Nigerian society could be felt in every facet of the nation. The sociopolitical system and structure of the Nigerian society is anchored on the egocentric political ideology that is materialistic in orientation. The youths, in their quest to know and explore, become the most hit of the faulty and dysfunctional socio-political structure of the state in which the rich become richer and the poor become poorer. The reason is simple; youths determine the feasibility of the socio-economic force of the society. Of a truth, the Nigerian society has no feasible and viable plans for her youths amidst her schedules thereby exposing the youths to different forms of ills and social vices. The affairs of the Nigerian society are piloted by men (political elites) who project themselves as gods and make policies to suit their selfish interests .Psalm 12:4 identifies such people who wield authority to get their lot as boasters who wield their ego thus they say "With our words we get what we want. We will say what we wish and no one can stop us". Such leaders have no agenda for the youths, neither is the technological status of the state their interest rather they siphon nation's economy. They parade under high political immunity. In such environment where everything goes in the name of leadership and democracy is customized by a few individuals, immorality becomes the fate of the people. Its effects are of grave consequences and the youths remain the most affected. Ngwoke in Chiegboka and Nwadialor observed that: 
Any failure of leaders to take the youth into account whether in civil society or in the church would be a grave and dangerous omission. To disregard the persistent and sometimes aggressive voice of the young anywhere in the world, and the refusal to meet their demands some way (not necessarily all the way) is to invite disaster. This is because in any society, state or church, they form the most vocal and strongest opposition to established order: they are the most active force...they gleam with illusion, aspirations and dreams. They cannot but be given a hearing whether in the society or the church, (p.130).

An overview of the different facets of the Nigerian society would buttress more the situation on ground concerning the plight of the youth in a morally decadent society. Proverbs 29:2 says: "Show me a righteous ruler and I will show you a happy people. Show me a wicked ruler and I will show you a miserable people." Every rational being in Nigeria could attest to the above provisions of the scripture when the leadership record of the Nigerian state is evaluated. A lot of ink had been spent by many scholars from different disciplines in trying to pin down the problem in and with Nigeria. Achebe (1983) appears to be the most cited author in this regard having lamented that the problem with Nigeria is leadership (p.11). The weather, air, land and climate of Nigeria is devoid of problems but her leaders are unwilling to take the responsibilities of leading by personal examples which is the hallmark of true leadership. Today, people opt for political positions not necessarily to serve. Jesus Christ identified himself as a servant leader in the gospel of Matt.20:28 who came not to be served but to serve. A good number of our political leaders are self-centered. In attempt to achieve their 
personal interests, they employ every possible means even if it entails murder. Disheartening enough, these political lords engage the youths as election thugs, riot promoters, character and human assassins as well as violence dispensers just to satisfy their personal interests. A good number of Nigerian youths have died while serving the ill-will of their political masters while some remain perpetual hooligans.

The story is not different when the educational sector is $\mathrm{x}$-rayed. The issue of education in Nigeria remains a sore point given the dwindling standard of education in Nigeria. A good number of Nigerian youths scramble for admission into the Nigerian higher institutions every year. As some find their way into the higher institutions, many lost out not necessarily because they did not pass the basic examinations, but consequent upon the tight policies of the powers that be who regulate the number of people to be admitted using the so called 'quota system'. Those who manage to be in school are saddled with inconsistencies in the school system as a result of strike and other related issues. In other to meet up with the academic calendar, lectures are moduled up and the students end up leaving the school half-baked. The effects of such situation among other things remain lack of proficiency in service and unemployable saga. One could therefore, understand in the light of the above discourse Obiefuna ( 2010) remark that "the average Nigerian youth today could be said to be inexperienced and untutored because of the unstable nature of education and educational institutions in the Nigerian system" (p.62). Nwodo(2010) traced the problem with Nigerian education to the military surge in governance. She articulated her point thus: "with the advent of the military in the governance of the country, standards began to fall. The system was militarized. The schools were deprived of adequate funding. Old infrastructures were not replaced or 
repaired...morale became low" (p.5). Okeke(2009) emphasizing on laxity on the part of the government added that:

Our government appears not to be aware that it is their responsibility to ensure quality education of its youth. They do not invest reasonably in education; they do not subvent schools... they do not make real efforts to subsidize education; scholarships for indigent and bright students have become a thing of the past, (p.30).

Consequently, indiscipline, cultism, sorting, sexual harassment and promiscuity became the order of the day. Again, given the situation where no clear distinction could be made between the educated and non -educated, some Nigerian youths prefer business to education. This is also coupled with the nonchalant attitude of the government in taking into consideration, the provision of technological institutes and vocational schools and the likes for youths for the acquisition of skills instead youths are left to roam about the streets and constitute nuisance and security threat to the society.

Similarly, unemployment has become a thorn in the flesh of the Nigerian youths. It is a bane that confronts the Nigerian youths with respect to integral living. The economic level of the nation is below optimal inspite of her potentialities and the possibilities that are calculable on account of Nigeria's' natural and physical wealth. Such a disheartening situation dawns on the youth. Sequel to this, some Nigerian youths have resorted to different kinds of social crimes such as robbery, kidnapping, drug smuggling, human trafficking, and prostitution and so on just to make ends meet. Because, we do not have skill acquisition centers and viable vocational institutes, many Nigerian youths go into business grudgingly 
living from hand to mouth without meaningful progress and yield. With the above observed situation, it becomes clear on why some Nigerian youths constitute social disorder, nuisance and security threats. Many of our youths Okeke (2009) observes plan to leave the country, and never to return. It is therefore, in the light of the observed odds that have swallowed the moral consciousness of our youths that the Church resolved to provide a befitting environment to maximize the intellectual potentials in youths in order to optimize their output while impacting positive changes to already dwindled and morally decayed society. The reason is simple; youths are the future hope of the nation for a glorious tomorrow.

\section{The Holy Family Youth Village and Moral Formation of the Youths}

The Fathers of the Second Vatican Council in their document Pastoral Constitution on the Church in the Modern World declared that: "The joy and hope, the grief and anguish of the men of our time, especially of those who are poor or afflicted in any way, are the joy and hope, the grief and anguish of the followers of Christ as well" (p.796). Apparently, the welfare of the members of the society remains the utmost concern of the Church.Youths in Nigeria are the most vulnerable in terms of the poor socio-political and economic malaise in the Nigerian society. Consequently, youths are not only materially poor but are also morally decadent. Conscious of the challenges that confront the Nigerian youths especially the university students, the Catholic Church in Onitsha Archdiocese under the leadership of Most Rev.Valerian Okeke the Archbishop of Onitsha who is also the Metropolitan of Onitsha Ecclesiastical Province resolved to bring the true mission of the universal church to the people especially the youths. Having observed 
that the quality of both the physical facilities and the living condition of our youths in many institutions of higher learning is nauseating and as such impact negatively on the moral, social and academic output of the students, the Church however, built hostels not only to ensure academic proficiency but to instill moral rectitude among the students.

Holy Family Youth Village project is a large complex of about 36 plots of land located in Amansea within a close proximity to Nnamdi Azikiwe University Awka. It consists of four hostel buildings (the fourth block is under construction) of three storey building each for both males and females (www.onitsha-archdioa.org/youthvillage awake.htm). Each of the hostels provides a total of 600 en-suite rooms with almost 1,200 bed spaces with several other amenities that facilitate good human living. Some of these facilities include portable water from a bore hole, 500Kva generator to augment Nigeria's epileptic power supply as well as inverter that gives light to every quarter of the environment, reading rooms at each floor, visitors lounge, good road and parking lot, canteen, laundry services, super market, internet cafe, salon, in-house security as well as a chapel for worship and more importantly a clean and descent environment in recognition of the idea that cleanliness is next to Godliness. These facilities are provided to ensure serene learning environment and qualitative living condition of the students. The Holy Family Youth Village has met the most challenging issues that confront students at admission such as problem of accommodation. With provision of air conditioned buses, students are taken to and fro to school thereby alleviating the students of the problem of queuing and struggling for buses. The environment in which the students live has a lot of influence on them. Environment in this context could be understood in the light of Aluko (2006) explanation as "the physical space and the surroundings in which man lives or resides" (p.299). The social aspect of the environment determines to a large extent the social behaviour of the human 
person. Obiefuna(2010) rightly observed that the development of individual persons within the society depends largely on influences they receive from their social environment."(p.59). On that note, the location of youth village is such that guarantees serenity and tranquility. These and more are for the purposes of boosting their inspirational dispositions.

The management of Youth village through the exercise of certain disciplinary measures checkmates most of the excesses found among youths. These excesses spring from freedom which has been observed as the permissible language of the body predominant among youths.Apparently,youths agitate for freedom to live the way they want without being regulated and often times they abuse freedom at the expense of self, morality and their future. Freedom Maurus (2007) says "is not the right to do as one pleases, but the liberty to do as one ought" (p.32). To avoid the effects of abused freedom, management of the Holy Family Youth Village regulates movement of opposite sex by abhorring opposite sex visitation into the rooms by making provision for lounge rooms where visitors could be attended to. Warnings are given to defaulters and in extreme cases suspension of defaulters serve as corrective measures to deter deviants.

The Holy Family Youth village also recognizes the need for both the body and the soul to be in harmonious coexistence by making provision for both indoor and outdoor games facilities that ensure both the physical and mental fitness of the individual. She equally organizes seminars, conferences and excursion tours for the students so as to enrich their minds economically, socially, mentally and otherwise. Female students are taught how to be independent in life through learning of some craft works as well as how to become efficient home makers' .With the establishment of St.Thomas Aquinas club; youths are encouraged to be domicile to the 
world of information for 'he who is not informed is bound to be deformed'. The Holy family Youth Village as an establishment has provided job opportunities to some youths who work as sales girls, hair stylists, tailors, cleaners, security men, drivers and others.

However, with Nwosu's remark in Ezeka (2002) that immorality has persisted in our society because many citizens no longer fear God (p.21). It therefore, becomes imperative that the students be directed towards God and things of God. Consequently, liturgical celebrations are held on daily basis, pious associations and prayer groups were introduced and the students enjoined to join for their spiritual and moral upkeep which will in turn have effect in their life affairs.

\section{Selected Agents of Moral Formation}

Morality remains as it were an indispensable factor hence human person and the society is concerned. It nurtures in the human person consciousness of virtues and values that make him a good person thereby developing his/her thinking skills of moral judgment with respect to what is right and wrong. Moral formation of the human person cannot be achieved in a vacuum. There are principal institutions with the task of seeing to the moral growth and inculcation of disciplinary measures in the human person. These institutions however, are referred to as moral agents. Odey (2009) defines a moral agent as:

A creature made in the image of God and imbued with conscience. He knows the difference between what is right and wrong, and he has the freedom to choose either, that which is wrong or that which is right. Above all, in the final analysis, he should be prepared to take full responsibility for his actions or inactions, (p.73). 
The family (home) remains the basic cell of the society among other notable agents of formation. In the family is found the father, the mother and the immediate family members (close knit-community). These people fundamentally are entrusted with the duty of nurturing and mentoring and guiding the human person especially the young. In the light of the above observed natural duty incumbent on the parents, Okeke (2009) identifies family "as the first school, the smallest unit, the first community, the first church, the basic centre of reference for a child; it falls on parents as a natural duty to be the first educator of their children"(42-43) .Basic values, virtues, norms and practices of the human society is expected of the parents to imbibe in their children. Obi remarked that "moral life ...is impossible without an adequate formation in virtue" (54). Some of these virtues include honesty, truth, respect for human life and dignity, love, tolerance, hardworking, chastity e.t.c. These values are for the good of the human person and the society at large. These values are enshrined in the way of life an individual is born into, in its attitude and practices. This brings to fore the inevitable role of parents in child upbringing. This goes to say that the values and virtues expected of the parents to impact in their children is not self-made neither is it optional. It embraces the whole gamut of the culture of the people which as it were cannot contradict the revealed truth. In view of this, Okeke (2009) added that since culture is the way of life of a people, parents should endeavour to bring up their children in the particular culture that is their heritage being particularly careful not to teach them what is contrary to revealed truth or Christian ideals. This, however, raises the need for a fortified moral home and noble characters among parents for it is only by living a moral life that the (parents) could infuse moral trainings in their children. Parents can only make moral impact 
in their children only if they are morally conscious, responsible and active in the society. Buttressing further on the place of family in moral formation of the child, Adukwu (2002) posits that the starting point of the moral development of any human person is the home. At home parents shape and model the life of their children in conformity with society's cherished norms, rules and values" (p.257). This is predicated upon the Africa's world view particularly the Igbo saying that no singular individual owns a child, rather the child belongs to the community (o buro otu onye nwe nwa,oha nwe nwa). At the early stages of a child development, the family has greater impact as the orientation acquired at this period is intensively and persistently held by the individual for a much longer time. Ebebe (2011) sounds more definite in this regard thus: "...it is clear that the home is where everything good or bad started (p.24). Therefore, setting high moral standard offers great corrections to the many corrupting influences from outside the home. Fathers of the Second Vatican council in her document Gravissimum Educationis (1965) uphold the family as the principal school of the social virtues which are necessary to every society. It remains the foundation of society where people learn, develop and grow to maturity.

Similarly, the church has a serious stake in the character and moral formation of the human person. The church achieves this in line with the revealed truth and the Christian ideals. According to Uwalaka (2008) "Church is the bearer of moral vision and moral force by bringing into public arena the revealed truth of Christ. The church serves as a pace setter and propagator of sound moral society" (pp.105-106). The divine mandate in the gospel of Matthew 28:19ff states "go therefore, make disciples of all nations...teach them... exposes the indispensability of the church not only as a mother but also a teacher towards the affairs of mankind. On that note, Fathers of Second Vatican Council in Gravissimum Educationis preface declared: 
For her past, holy mother church, in order to fulfill the mandate she received from her divine founder to announce the mystery of salvation to all men and to renew all things in Christ, is under obligation to promote the welfare of the whole life of man including his life in this world in so far as it is related to heavenly vocation; she has therefore a part to play in the development and extension of education, (p.643).

Church is the society's characters molder. She upholds and enforces virtues that perfect the human person. Truth, honesty, hard work and humility among other virtues take precedence while the church exerts pressure in character formation of the members of the society. She spells out the gain of living virtuous life for the conformist and the deficit for the deviants. It is the interest of the church to see that all the adopted children of God should experience healthy growth and share the true life that is embedded in living moral and virtuous life. To achieve this task, the church employs noble measures in partnership with other agents of moral formation. Through the use of media, organization of retreat, seminars, workshops at different levels including educational institutions. She gives her own quota towards the realization of a morally sound human society.

Furthermore, just like parents and the church, the state is also a stake holder in character formation of the human person. The state through the provision of educational institutions acquaints the citizens with basic norms, and values of the society. The Fathers of the Second Vatican Council would opine that: 
It is the duty of the state to ensure that all its citizens have access to an adequate education and are prepared for the proper exercise of their civic rights and duties... It is the duty of the state to ensure quality education, set good standards for the teacher and students, enforce rules, encourage the extra-talented students through scholarships and grants, give study loan or scholarship to indigent but deserving students, (p.6).

Apparently, education is a vital tool in proper formation of the youths so as to ensure continuity in terms of treasured patrimony for both present and future generations. Okeke (2009) citing Pope John Paul 11 asserts that education helps individuals to be more human, leads them ever more fully to the truth, instills in them growing respect for life and trains them in right interpersonal relationship. The point above makes youth education inevitable. However, the impact of education in our Nigerian society cannot be denied but the problem lies in the observations of Ugwu (2010) that "apparently the more we find education permeating the human population, the more depraved man becomes morally" (p.46). This is a pointer to the ontological aberration in what the society considers virtuous. It is important to note that the above highlighted agents among others work towards inculcating and shaping the youths morally and otherwise and the holy family youth village is a consolidated effort of the church in realizing this goal.

\section{Conclusion}

The level of porosity and erosion of morality in Nigeria is quite disheartening and unfortunate. Worse still the youths are 
the most hit of the hydra-headed cancerous menace. This could be attributed among other factors to the poor moral and sociopolitical structure and system of the Nigerian society. Considering the indispensability of the youths in every optimistic human society, it becomes imperative that those values, virtues, norms and code of conduct without which human co-existence could be considered impossible should be inculcated in the youths. The influence of the social environment on the youths cannot be argued. Therefore, there is a need to catch the youths young and impact in them basic moral tips and principles of the society. This would go a long way to checkmate moral decadence among the youths. Onitsha Ecclesiastical province under the leadership of Archbishop Valerian Okeke had set the pace. The church considers the youths as the greatest legacy that could be bequeathed to mankind and the Holy Family Youth Village project is aimed at the formation and realization of quality human beings. This work, challenges individuals, industrialists, NonGovernmental Organizations (NGO's) and the government to be more proactive to the welfare of the youths. The state can help by tightening its belt and living up to expectations so as to ensure sound moral education that will not only benefit the youths but also the entire human race. There is a need to encourage moral education,establish skill acquisition centres and by so doing give a sense of direction to the youths for the realization of a morally sound and formidable Nigerian society.

Amara M. Uzoigwe is of the Department of Religion and Human Relations, Nnamdi Azikiwe University, Awka. 


\section{References}

Achebe, C. (1983). The Trouble with Nigeria. Enugu: Fourth Dimension.

Adukwu, R.M. (2002). Self-Moral Transformation: The Determinant of a Corrupt-free Nigerian Society. in C. O. T. Ugwu (ed.). Corruption in Nigeria: Critical Perspective. Nsukka: Chuka Educational Publishers. 251-259

Aluko,M.A.O. (2006). The Environment, Ecosystem and Social Life. In K.A. Ogunbameru \& W.R. Rotimi (eds.) Man and His Social Environment. Ibadan: Spectrum Books Ltd. 298-315

Austin, F. (1988) Vatican II: The Conciliar and Post Concciliar Documents. Dublin: Dominican.

Chiegboka A.B.C.\& Nwadialor K. (2010). Crisis Management in Youth Leadership: An Evaluation of Paul's Teaching in I Timothy 4:12. Journal of Religion \& Human Relations.Vol.1No.3,129-139

Ebebe, C.O. (2011). Together Let Us Create a New Generation. Nimo: Rex Charles \& Patrick Ltd.

Eboh, M. P. (2001). Dialogue, Democracy \& Morality. Owerri: Springfield Publishers.

Ezeka, C. (2002). Christian Living in an Immoral Society. Torch Magazine. No. 124, 21-24

Iwenofu, M.J. (2010). Religious and Moral Education and its impact on National Development. Journal of Bigard Memorial Seminary. 48-61

Maurus, J. (2007). The Joy of Being Human. Mumbai: Better Yourself Books.

Monye, M.A. (2010). Saint Paul's Moral Thought: A challenge to moral dilemmas in the contemporary African Church. The Preceedings of $24^{\text {th }}$ Conference of the Catholic Theological Association of Nigeria CATHAN. Makurdi: Aboki Publishers. 
Nwodo, M.J.T. (2010). The Dwindling Standard of Education in Nigeria: The Way Forward. Magazine of Immaculate Heart of Mary Mother of Christ Postulate (IMMAPOST) 8th Edition.5-7.

Obi, E.O. (2008). Social Attitude and the Moral Regeneration of Nigeria: A virtue Perspective. The Nigerian journal of Theology. Vol.22 47-62

Obiefuna, B.A.C. (2004). The Youth on Fire. Nimo: Rex Charles \& Patrick Ltd.

Obiefuna, B.A.C. (2010). Moral Decadence among the Youth in Nigeria: Lessons from Paul the Apostle. African journal of local societies Initiative.58-65

Odey, J. (2009). The Politician as a Moral Agent: A sober reflection on the predicament of the Igbo. In F.C. Aghamelu, S.C.Okeke \& C. Asomugha (Eds.). Politics as public service: The legacy of Mr. Peter Obi. Awka: Strong Tower. 70-96

Okeke V.M (2009). Our Greatest Legacy. Enugu: Snaap press Ltd.

Omoregbe, J. (2003) Ethics a Systematic and Historical Study. Lagos: Joja press Ltd.

Okwueze, M.I. (2004) Religion and the Decaying Moral

Values in Contemporary Nigerian Society. In M.I.

Okwueze (Ed.) Religion and Societal Development

Contemporary Nigerian Perspective. Lagos: Merit International Publications. 240-254

Ugwu, C.I. (2010) Folklore in Igbo society: A Panacea to the Threat of Home Video. African Journal of Local Societies Initiative. 45-51

Utsua,T.P. (2010) Religion and Moral Values in African Religion. African Journal of Local Societies Initiative. $52-57$ 
Uwalaka J. (2008) The Church as Conscience of a Nation. In I. Onyeocha (Ed.). The Church as Agent of Progress and Development. Owerri: Imo State University. 121-133 